\title{
Unpacking the Meaning of Conflict in Organizational Conflict Research
}

\author{
Mikkelsen, Elisabeth Naima; Clegg, Steward
}

\author{
Document Version \\ Accepted author manuscript \\ Published in: \\ Negotiation and Conflict Management Research
}

DOI:

$10.1111 / \mathrm{ncmr} .12127$

Publication date:

2018

License

Unspecified

Citation for published version (APA):

Mikkelsen, E. N., \& Clegg, S. (2018). Unpacking the Meaning of Conflict in Organizational Conflict Research. Negotiation and Conflict Management Research, 11(3), 185-203. https://doi.org/10.1111/ncmr.12127

Link to publication in CBS Research Portal

\section{General rights}

Copyright and moral rights for the publications made accessible in the public portal are retained by the authors and/or other copyright owners and it is a condition of accessing publications that users recognise and abide by the legal requirements associated with these rights.

\section{Take down policy}

If you believe that this document breaches copyright please contact us (research.lib@cbs.dk) providing details, and we will remove access to the work immediately and investigate your claim.

Download date: 26. Apr. 2023

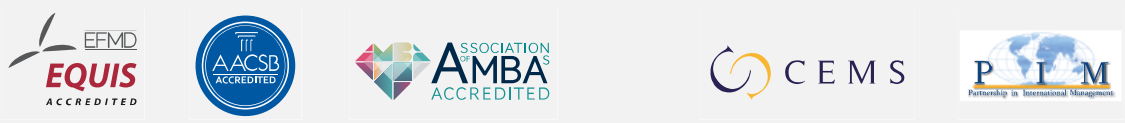




\section{Unpacking the Meaning of Conflict in Organizational Conflict Research}

\section{Elisabeth Naima Mikkelsen and Steward Clegg}

Journal article (Accepted manuscript*)

\section{Please cite this article as:}

Mikkelsen, E. N., \& Clegg, S. (2018). Unpacking the Meaning of Conflict in Organizational Conflict Research. Negotiation and Conflict Management Research, 11(3), 185-203. https://doi.org/10.1111/ncmr.12127

This is the peer reviewed version of the article, which has been published in final form at DOI: https://doi.org/10.1111/ncmr.12127

This article may be used for non-commercial purposes in accordance with Wiley Terms and Conditions for Self-Archiving

* This version of the article has been accepted for publication and undergone full peer review but has not been through the copyediting, typesetting, pagination and proofreading process, which may lead to differences between this version and the publisher's final version AKA Version of Record. 


\title{
Unpacking the meaning of conflict in organizational conflict research
}

\author{
Abstract \\ In this conceptual essay, we review the field of organizational conflict in order to unpack how it has \\ been constructed genealogically and with what consequences by investigating three major shifts in \\ theorization that have occurred over the past six decades. First, a move away from viewing conflict \\ as dysfunctional to viewing it as constructive. Second, a shift from normative prescriptions to \\ descriptions of what disputants do in conflict. Third, a shift from psychological functional analyses \\ to studying conflict as an organizational phenomenon. We find that three distinct and essentially \\ contested conceptions frame studies of conflict at work: conflict as a distinct behavioral \\ phenomenon, conflict as an instrumental means of achieving something else, and conflict as a social \\ construction contingent on how reality is perceived. This conceptual essay adds to current thinking \\ in organizational conflict research by emphasizing how philosophical and political assumptions \\ about conflict can be seen to have framed knowledge production within the field when it is viewed \\ historically.
}




\section{Introduction}

The organizational conflict research literature is large, diverse and flourishing. That the literature should be so extensive is not surprising: conflicts between peoples are a constant of history and chroniclers have recorded such conflicts since early literate times (e.g. Polybius, 1922; Thucydides, 413 BCE). Throughout history the major organizations involved in conflicts have been states and armed forces. In recent times, the focus has broadened to encompass conflicts within organizations more generally. In many respects, this focus owes a great debt to Marx's (1976) view of conflicts born of the contradictions of class struggle as the motor of history, although an explicitly Marxist focus is far less apparent today than in its heyday in 'conflict sociology' (Collins 2009). Today, there are far more nuanced and substantively grounded accounts of conflict in organizations and at work that are both more granular and less dependent on grand theories or macro-organizational clashes of states or classes. Of course, the field is enormous and in one paper we cannot expect to cover all of it; we shall be sociologically selective in focus.

A number of scholarly analyses of the organizational conflict literature have been published over the years to frame and provide an overview of the field of organizational conflict: Putnam and Poole (1987) offered a thorough coverage of conflict that they organized in terms of three levels of analysis: interpersonal, intergroup and inter-organizational. In turn, the significant contributions of Putnam have been analyzed by Paul, Geddes, Jones and Donohue (2016) in terms of the communication perspective of conflict, interaction analysis, the bona fide group perspective, and bounded emotionality. Lewicki, Weiss and Lewin (1992) identified and categorized approaches to conflict in terms of micro level models of conflict as well as negotiation and third-party processes. Wall and Callister (1995) reviewed literature about the causes and effects of conflict and about disputants and third parties' roles in conflict management. Van de Vliert (1998) reviewed 
literature focusing on the escalation and de-escalation of conflict. De Dreu and Gelfand (2008) synthesized literature on the sources and effects of conflict across different levels of analysis: individual, group, organization, and national culture.

Despite these thorough accounts of the state of the art within the field of organizational conflict and the field's longevity as a research topic, a research gap remains: we rarely encounter discussions about the meaning of conflict and its epistemology, even though the literature on organizational conflict differs markedly in its grounding of the many conceptions of conflict. Consensus on a widely agreed upon definition of conflict has been called for by numerous scholars in management and organization science (e.g. Barki \& Hartwick, 2004; Fink, 1968; O'Connell, 1971; Schmidt \& Kochan, 1972; Spector and Bruk-Lee, 2008; Tjosvold, 2008). They see the lack of consensus as a major obstacle to progress within the field because research results cannot be generalized from one study to another. Given the significant difference in epistemologies and, indeed, ontologies, underlying the field, this seems a pious but unrealistic ambition. Another option, rather than calling for consensus where there is little sign of it being evidently achievable, is to appreciate that conflict may be one of those 'essentially contested concepts' that Gallie (1956) noted, along with power (Lukes 2005). To say it is essentially contested is to propose, with Garver (1978, p.168), that:

"The term essentially contested concepts gives a name to a problematic situation that many people recognize: that in certain kinds of talk there is a variety of meanings employed for key terms in an argument, and there is a feeling that dogmatism ("My answer is right and all others are wrong"), scepticism ("All answers are equally true (or false); everyone has a right to his own truth"), and eclecticism ("Each meaning gives a partial view so the more meanings the better") are none of them the appropriate attitude towards a variety of meanings." 
When we approach the study of conflict from a genealogical perspective, we see that the many different definitions of conflict arise from diverse epistemological, methodological and theoretical positions and are an inevitable consequence of diverse social science practices. These different positions involve endless disputes about their proper uses on the part of their users and cannot be settled by "appeals to empirical evidence, linguistic usage, or the canons of logic alone" (Gray 1977, p.344). Essentially, contested concepts are evaluative, creating inherently complex concepts depicted in mutually incommensurable terms by positions that refer to different assumptions and traditions of theorizing. Because of this, there is no one best instance of an essentially contested concept although, in terms of their interpretative breadth and depth, some will be better, more useful, than others (Swanton 1985).

Thus, as we see it, the many different definitions of conflict are not a problem because they obstruct generalizability; the problem is rather that scholars conceptualize conflict on the basis of assumptions that we all know - and all agree on - what conflict is. It is therefore the failure to be specific about which epistemological and ontological meaning of 'conflict' is being indexed, as it were, rather than the absence of agreement on a common definition of conflict, which creates conceptual ambiguity and obscures conceptual advancements in conflict research.

Given this lack of openness about how to conceptualize conflict, an opportunity arises to clarify and raise awareness of the different theoretical assumptions embedded within different conceptions of conflict. The purpose of our essay is therefore to identify distinct ways of conceptualizing conflict in the theoretical domain of organizational conflict. With the organizing principle that 'conflict', however it is theoretically conceptualized in the literature, is the object of study, we examine relevant theoretical and empirical contributions to address the research question, how has organizational conflict been constructed genealogically, and with what consequences? 
In applying a genealogical approach to study conceptions of conflict in the modern history of conflict research we are greatly inspired by Foucault (2003), who deploys genealogy to question dominant values of current conceptions in the history of knowledge. 'Conflict' can be analyzed using a genealogical approach to record movements (Burrell, 1996). Burrell views movements as recording changing attention and meanings within a theoretical domain. Inquiry into movements and shifts in the genealogy of conflict research reveals distinct changes in conceptualization. Genealogy allows us to uncover the taken-for-granted assumptions about conflict, which we observe in the different strands of conflict research and expose struggles for dominance in the theorizing of conflict.

Our contribution in this conceptual essay is twofold. First, we show that the study of organizational conflict has undergone three major shifts over the past six decades that have established diverse traditions of theorizing, creating specific grounds for contestation. The shift from viewing conflict as dysfunctional to viewing it as constructive created contestation over the functional essence of the term; the shift from normative prescriptions to descriptions of what disputants do in conflict generated contestation over the descriptive essence of the term, and the shift from psychologically oriented analyses centered on individual level dispositions to studying conflict as an organizational phenomenon generated contestation over the performative essence of the term. While these shifts have occurred separately over periods of several decades, they have broadened and generated new strands of conflict research. Second, we identify three distinct and essentially contested theoretical positions on the meaning of conflict that frame studies of conflict at work. Here we expose the taken-for-granted assumptions inherent in the different strands of conflict research.

\section{The Functional Essence of Conflict}


Current debates about conflict in the organizational conflict literature replay the divisions of 1950s functionalist sociology (Coser 1956). The essential question that constitutes these debates asks whether conflict is a negative phenomenon that is destructive and disruptive or if it could be a constructive process with positive consequences (for such debates, see De Dreu, 2008; Tjosvold, 2008; and recent meta-analytic reviews by DeChurch, Mesmer-Magnus, \& Doty, 2013; De Dreu \& Weingart, 2003; de Wit, Greer, \& Jehn, 2012; O’Neill, Allen, \& Hastings, 2013). The debates are rooted in a major shift occurring from the 1950s to late 1970s that moved from a dysfunctional view of interpersonal conflict to a functional view. During this period, conflict slowly came to be seen as a constructive force that was potentially beneficial for the organization, if the right kind of conflict occurred and was handled correctly, rather than as a sign of breakdown and deviance from organizational harmony and equilibrium. Conflict could be beneficial because it could improve performance, innovation and decision-making in organizations. The move towards conceptualizing conflict as constructive may be thought of as a catch-up with the traditions of sociological analysis associated with Simmel (1955) and Coser (1956). Although our main focus in this conceptual essay is to review modern conflict research; that is, research from the 1950s and onwards, we first briefly examine the logical notions of conflict present in the classical historical literature on conflict.

\section{Conflict in Classical Social Theory}

The abundance of historical literature on conflict has mainly dealt with controlling, avoiding, and eliminating social conflict (Rahim, 2000). Classical philosophers such as Plato and Aristotle assigned conflict a pathological status: viewing it as a threat to order and the success of the state. These philosophers argued that the state's responsibility was to maintain order and keep conflict to an absolute minimum (Shipka, 1969). Seventeenth-century social contract theorists, such as Thomas Hobbes and John Locke, argued in a similar vein that government's central role was to control conflict so as to establish order in social relations. By the nineteenth century, however, 
major philosophical contributions from the dialectical perspective inspired by George Wilhelm Friedrich Hegel (1975) and continued by Karl Marx (1976) identified conflict as the necessary engine of social change.

\section{Organizational Conflict as Dysfunctional}

In modern works on organizational conflict, conflict was largely regarded as a dysfunctional phenomenon, "altogether bad" (Fink, 1968, p. 445), and as "a breakdown in standard mechanisms of decision-making" (March \& Simon, 1958, p. 112). Conflict represented situations of ambiguity, "basically different from 'co-operation”" (Mack \& Snyder, 1957, p. 212). Conflict was often depicted as part of a conflict-cooperation dichotomy, where one is defined in terms of the absence of the other. Conflict situations were considered best eliminated so that cooperation that produces order could take place. These views were aligned with assumptions that organizations are rational, linear and predictable systems, in which stability is to be achieved through planning and control (Perrow, 1967). Conceptually, conflict was associated with self-interested actions that deliberately undermined collectively defined goals (Boulding, 1957; Fink, 1968). Conflict was primarily treated as a subset of competition, since it was assumed that all cases of conflict would involve some level of competition. The ambiguous distinction between conflict and competition was criticized by scholars such as Katz \& Kahn (1978), Mack \& Snyder (1957) and Schmidt \& Kochan (1972) who sought to limit the concept of conflict to overt behavior or social interaction processes occurring subsequent to the perception of mutually incompatible goals or values.

Conflict as a distinct behavioral phenomenon. Conflict was conceptualized as something deliberate and goal-directed by at least one of the parties involved. We see assumptions that conflict involved an "overt behavioral outcome (...), that is, (...) actual interference or blocking" (Schmidt \& Kochan, 1972, p. 363). It could be passive or active. In this view, perception of goal or value 
incompatibility was seen as a necessary precondition for conflict. Katz and Kahn (1978) saw conflict as "the collision of actors" (p. 613), in a distinct behavioral conceptualization of the phenomenon that required an observed clash in which two bodies collide in conflict with each other. Schmidt and Kochan (1972) termed this a "behavioral conceptualization of the process of conflict" (p. 359). The roots in classical behaviorism and its dependence on Newtonian accounts of mechanics could not be clearer.

For behaviorists, conflict was essentially seen as a breakdown in relationships between individuals. This view identified conflict as a dysfunctional phenomenon. Experimental studies were the preferred methodology to study the strength and direction of relationships between variables in conflict. Objectivist-realist research positions and positivist thinking were premised on assumptions about how experimentally contrived situations mirrored the 'real' world. Privileging direct observation of behavioral components, conflict was largely regarded as a matter of observable behavior, which could be separated from other elements such as context (Druckman, 2005). Critics (e.g. Barley, 1991) made the case that experimental settings were contrived, posing problems for generalizing results to real-world situations, conflict research moved its methodological gaze onto settings in which research participants actually worked.

\section{Organizational Conflict as Functional}

To advance beyond the one-dimensional view of conflict as the disruptor of order, researchers began focusing on its positive dynamics and consequences. This trend started with Coser, who in 1956 published his now classic book on The Functions of Social Conflict. Coser contended that conflict is not always socially destructive but rather an essential mechanism in the positive evolution of society. Subsequent organization theorists such as Pondy (1992) and Thomas (1992) endorsed and contributed to this changing view of conflict in organizations. In 1967, Pondy argued that conflict is neither good nor bad but must be assessed in terms of its individual and 
organizational functions and dysfunctions. In his early work conflict was seen as disturbing the equilibrium in organizations, an assumption implicit in nearly all existing organizational studies of conflict at that time. Pondy radically revised his ideas subsequently: by 1992, he saw conflict as "not only functional for the organization, it is essential to its very existence" (1992, p. 260). The change in Pondy's conception of conflict in organizations epitomized an emerging shift within the field of conflict research from viewing conflict as dysfunctional to viewing it as potentially functional if the right kind of conflict occurred. Thomas (1992) also saw conflict as being potentially constructive, inspiring research that began to distinguish between dysfunctional and functional conflict. This research led to the establishment of the conflict type framework and identified the categories of task and relationship conflict, and later process conflict and status conflict.

Task conflict concerns disagreement about the content of the work that is being performed; relationship conflict is seen to exist when there are interpersonal incompatibilities arising from differences in personality or opposing values (De Dreu \& Beersma, 2005; Jehn, 1997). Such disagreements about personal issues often represent ego threats because the issues in relationship conflicts are strongly interwoven with the self-concept (de Wit et al., 2012). Process conflict is closely related to task conflict: whereas task conflict has to do with the actual task, process conflict concerns the process of task accomplishment in terms of how resources and duties are delegated, how the task is done (Jehn, 1997). The concepts of task and relationship conflict are widely used in conflict research and are therefore well-established concepts in the literature. The concept of process conflict is accepted as an important concept (see e.g. de Wit et al., 2012; Greer, Jehn, \& Mannix, 2008; Lê \& Jarzabkowski, 2015) but application is still limited. More recently, the concept of status conflict (Bendersky \& Hays, 2012) has been added to the collection of conflict types. 
Status conflict concerns disputes over members' status positions in their group's social hierarchy and it is viewed as being particular detrimental to group performance.

Relationship conflict affects identification and trust negatively (Jehn, Greer, Levine, \& Szulanski, 2008), and interferes with performance by generally lowering effectiveness, creativity, and innovativeness (De Dreu \& Weingart, 2003; Farh, Lee, \& Farh, 2010; Jehn, 1995; 1997). When poorly managed, relationship conflict is regarded as having negative long-term consequences for individual health and wellbeing (De Dreu, van Dierendoncck, \& Dijkstra, 2004). Recent research suggests that relationship conflict leads to biased information-processing and rigid stances, which negatively affect decision-making. (de Wit, Jehn, \& Scheepers, 2013). By contrast, task conflict has traditionally been seen as more likely to be constructive due to its ability to enhance decisionmaking quality by motivating team members' search for optimal decisions and solutions (Amason, 1996; De Dreu, Harinck, and Van Vianen, 1999; Olson, Parayitam, \& Bao, 2007). Task conflict is found to be positively related to individual creativity and innovation (DeDreu, 2006), task commitment and member satisfaction (Bayazit \& Mannix, 2003; Behfar, Mannix, Peterson, \& Trochim, 2011). Task conflict is often viewed as healthy and necessary because it stimulates discussions and prevents premature consensus, leading to enhanced work-team effectiveness and performance (De Dreu \& Beersma, 2005; De Dreu \& Van de Vliert, 1997; Jehn, 1994; 1995; 1997; Tjosvold, 1991). For example, Jehn and Mannix (2001) argued that "[m]oderate levels of task conflict have been shown to be beneficial to group performance on certain types of tasks" (p. 239).

Since the 1980s, a major strand in organizational conflict research has concentrated on refining the conflict-type framework to distinguish between negative and positive, or productive, conflicts in organizations, by mapping out how "these two types of conflict differentially affect work group outcomes" (Jehn, 1997, p. 531). Recently, task conflict has been seen to exhibit positive relations with team performance specifically in decision-making teams (O’Neill et al., 2013) top- 
management teams (de Wit et al., 2012) and in teams exhibiting a climate of psychological safety (Bradley, Postlethwaite, Klotz, Hamdani, \& Brown, 2012). Despite disagreements, task conflict is commonly considered constructive and relationship conflict dysfunctional.

Conflict as an instrumental means. In many of the works on functional organizational conflict cited above conflict is assumed to be an instrumental means to achieve authoritatively sanctioned ends. These assumptions can be summed up by Tjosvold's (2006) statement that "it is through conflict that teams can be productive and enhancing and leaders effective" (p. 92). Depending on the situations and the kind of outcome desired by management, we see a widespread interest within the literature on how attain the 'right' kind of conflict for the achievement of goals. By having a primary focus on what makes one type of organizational conflict better than another, interests have developed into discovering how to manipulate the system to reduce those conflicts perceived as 'bad' for the organization and stimulate other types of conflict deemed constructive, or productive, for increasing performance.

Within this strand of conflict research, the preferred methodology has been survey instruments designed to measure conflict intensity and conflict levels (see Jehn, 1995; Jehn \& Mannix, 2001; Shah \& Jehn, 1993; Behfar et al., 2011) at primarily the interpersonal level, on the presumption that if it is measured, it can be managed. To be measurable, conflict has to be acknowledged and verbalized by disputants. Informed by positivist epistemology, surveys are conducted from an objectivist-realist research position. This methodology ontologically presupposes an objective reality that can be encapsulated in central, distinctive and universal concepts (Hatch \& Yanow, 2008). The concepts of task and relationship conflict were taken to represent essential features defining conflict in organizations. There are, however, evident objections to the instrumental approach to studying conflict and whether the relationships between conflict types and performance should be so simple. It is particularly important to correctly 
diagnose task and process conflict, to harness the generative effects of conflict (Lê \& Jarzabkowski, 2015) and that the manner and intensity of conflict expression influences conflict processes and subsequent outcomes (Weingart, Behfar, Bendersky, Todorova, \& Jehn, 2015). Such studies move towards recognizing processual components of perception, interpretation, and expression as critical aspects influencing any relationships between conflict and performance. Static survey instruments will not capture data that is appropriate to these considerations.

Summarizing, this first shift embraced a normative and functionalist view emphasizing that organizational conflict is a constructive, productive force benefiting the organization if the 'right kind' of conflict occurs, rather than being one that is dysfunctional. Whereas early modern organizational conflict research regarded conflict as dysfunctional and focused on ways to remove it, subsequent analysts began to see conflict as intrinsic to human relationships, conceptually distinguishing between dysfunctional and constructive conflict. This instrumental orientation created contestation over the functional essence of conflict.

\section{Normative or Descriptive Practice of Conflict?}

Between the 1970s and 1990s, a second shift occurred within the strand of conflict research that focuses on interpersonal conflict management and resolution. During this time, scholars moved away from focusing on normative prescriptions of what disputants should do in conflict situations to focusing on what disputants actually do in practice. The shift reflects the notion that moral prescription never defeats empirical analysis. Morrill (1989) and Wall and Callister (1995), in particular, called attention to this shift.

\section{Normative Practice}

The normative school emphasized prescriptive approaches to conflict resolution. Sometimes its advice was generated from fairly abstract presuppositions: in the work of Raiffa and those 
influenced by him and with whom he worked, for instance, there was an explicit framing of conflict in terms of economics and game theory, often quite mathematically and statistically dense (Raiffa, Richardson and Metcalf, 2003; Raiffa, 1982). Other times the focus was on the practical steps that could be identified that disputants should take to deal with conflict, its causes, and consequences (Deutsch, 1973; 1990; Hocker \& Wilmot, 1991). Disputants should acknowledge the conflict, distinguish between interests and positions, listen attentively and speak so as to be understood by each other. Most of these steps are founded on the belief that it is through changed behavior that conflict may be dealt with or resolved. Other approaches, such as group- and interpersonal interventions (Walton, 1969) and collaborations were also recommended as 'best practices' for dealing with conflict (Thomas, 1976). Eiseman (1978) and Gray (1985) encouraged disputants to think about the conflict not only from their own but also from the opponent's position to enable a focus on what could be jointly achieved. Tjosvold (1985) advised disputants to be open-minded and recommended that cooperative goals could be established through open discussion of opposing views (Tjosvold, Dann, \& Wong, 1992). Deutsch's (1949) theory of cooperation and competition and definition of conflict as incompatible activities (1973), where one person's actions interfere or get in the way of another's action, inspired much normative research. Its dominant notion of conflict presumed a blend of cooperative and competitive motives. Whether protagonists in conflict believed their goals to be cooperative or competitive would affect their expectations and interactions in resolution of conflict.

Recent contributions from the normative school similarly prescribe behavioral steps to deal with conflict, by recommending, for example, that disputants discuss the conflict with third parties outside the conflict (Myers \& Larson, 2005), develop conflict-competent organizations through the use of constructive communication techniques (Runde, 2014), and explore their different preferences, priorities and resources (Bordone \& Morffitt, 2006). In all these prescriptive 
approaches, we see assumptions that the purpose of conflict management is to get the strategy for personal conflict management right so that conflict will lead to productive outcomes. The normative school of conflict management research therefore views conflict as a distinct behavioral phenomenon and as an instrumental means of achieving something else.

\section{Descriptive Practice}

Early empirical research into descriptive conflict handling confirmed that many disputants essentially engage in the prescriptions offered by the normative school. Blake and Mouton's (1964) development of the dual concern model, refined through the Kilmann and Thomas (1977) conflict MODE instrument, focused specifically on styles for personal conflict management. Two dimensions shape the model: concern for self and concern for others (Rahim, 1983). Variations of the dual concern model shaped the development of survey instruments for examining conflict management (Pruitt, 1983; Putnam \& Wilson, 1982, Rahim, 1983, 2000; 2002; Renwick, 1975), which measure the self-reported use of five core conflict management styles: forcing/dominating, avoiding, accommodation/obliging, problem solving and compromising.

Although its development took place several decades ago, we find that variations of the model are still widely used to examine individuals, groups and management's conflict management options and their relationships to a range of topics: personality (Antonioni, 1998; Chan, Sit, \& Lau, 2014), leadership styles (Saeed, Almas, Anis-ul-Haq, \& Niazi, 2014), emotional intelligence (Schlaerth, Ensari, \& Christrian, 2013), effectiveness and performance (Choi, 2013, DeChurch et al., 2013; Tanner, 2014), effectiveness of decision making in workgroups (Kuhn \& Poole, 2000), innovation (Song, Dyer, \& Thieme, 2006), gender and organizational status (Brewer, Mitchell, \& Weber, 2002; Aquino, 2000), expression of dissent (Goodboy \& Bolkan, 2013) and team role preference (Aritzeta, Ayestaran, \& Swailes, 2005). Although the instruments used to measure conflict management styles have been criticized for positioning the five core styles of conflict 
management as all-inclusive (Wall \& Callister, 1995), they still provide the preferred way of examining how disputants manage their conflicts and how their doing so affects various aspects of organizational life. Their popularity, Wall and Callister (1995) argue, stems not only from their ability to consolidate a great number of techniques into approximately five styles but also from their ability to predict how strategies used in conflicts affect conflict outcomes. Thus, the main focus in descriptive conflict management research has been on strategies for managing personal conflict to achieve productive outcomes. The underpinnings of the functionalist view that conflict must be doing some 'good' are evident. Descriptive practices thus view conflict as an instrumental means to achieve something else.

The normative-to-descriptive shift was also evidenced the field of the behavioral decision theory approach to conflict and negotiation, which documented the many biases that keep negotiators from negotiating 'rationally' (Thompson, 1990). Bazerman, Loewenstein and Moore (2002) for example showed that the frame is switched to one of institutional rather than personal values, to highlight the role of institutionalized self-serving biases that lead professionals, such as auditors, to view data in a light that reflects what they want to see. From this perspective the conflicts that occurred over the role of auditing in the wake of the Enron and Arthur Anderson case were productive because they recommended a reformed role for independent auditing that would minimize institutionalized self-serving biases.

Summarizing, as researchers began to measure individual conflict management styles of conflicts, conflict research experienced a second shift away from normative ideas about how conflict should be managed. This shift from normative prescriptions to descriptions of what disputants do in conflict generated discussion about the descriptive essence of conflict. For the purpose of studying conflicts, researchers (e.g. Kilmann \& Thomas, 1977; Rahim, 1983) developed survey instruments to measure individual styles of conflict management. Although widely used, 
instruments that measure individual styles of conflict management have been criticized for being premised on a simplistic two-dimensional description of conflict management.

\section{Dyadic or Organizational Conflict?}

Morrill (1989) and Barley (1991) alerted the field to a third shift emerging from the late 1980s and onwards. These scholars challenged the traditional psychological and functionalist analyses that assumed conflict and conflict management to be dyadic phenomena and moved attention towards an understanding of conflict as an organizational phenomenon. This shift may be thought of as a realization that it is practices embedded in social structures - as well as people's psychologies - that matter.

\section{Dyadic Conflict}

In the 1980s and 90s, theorists (King \& Miles, 1990; Knapp, Putnam \& Davis, 1988; Olekalns et al., 2008; Womack, 1988) began to criticize the emphasis on the individual as the sole benchmark for determining how conflict will develop. Recognizing that individuals act in dyads or groups, they called for a change of focus in conflict analysis, arguing that conflict should not be seen as unidirectional but should take into account actual interactions. Psychological and functionalist analyses (e.g. De Dreu, 1997; Jehn, 1995) began to approach conflict and conflict management as dyadic phenomena, using experiments and survey instruments to investigate conflict and negotiation in conflict. While generating important knowledge for understanding specific aspects of conflict and conflict management this literature implicitly assumed that all conflict, whether individual, group, or inter-organizational, tended to follow the same principles of interaction dynamics premised on person-to-person dyads (Barley, 1991; Clegg, Mikkelsen, \& Sewell, 2015). The dyadic level of analysis, often conglomerated into the term 'interpersonal conflict' (Barki \& Hartwick, 2004), was assumed to represent all organizational conflict. More recently, drawing on 
the strategy field, Borbély and Caputo (2017) have shifted analysis of negotiation to include negotiation at the organizational level.

Barley (1991) and Kolb and Putnam (1992) view conflict as more than either an individual or interpersonal event. Within the dominant psychological theorizations of conflict and conflict management in particular, conflict often became separated from the organizational context in which it occurred, thereby neglecting its expression as situated action (King \& Miles, 1990; Knapp et al., 1988; Somech, Desivilya, \& Lidogoster, 2009). Survey instruments, together with experimental methodologies failed to include a variety of organizational sources in the examination of conflict and worked from an asocial and compartmentalized conception of the phenomenon (Barley, 1991; Knapp et al., 1988). A consequence is that conflicts between staff and management are defined as private problems that must be resolved and managed individually: the organization is not responsible (Bartunek et al., 1992; Martin 1992). A shift towards seeing conflict as a social and cultural phenomenon, developed.

\section{Organizational Conflict}

Analysts within the field of organizational conflict (e.g. Gray, Coleman, \& Putnam, 2007; Kolb \& Bartunek, 1992; Morrill, 1989; 1995; Sheppard, 1992) began to argue that the structural and cultural context in which organizational conflict occurs is critical. Different sources of conflict, for example, the allocation of work between entities, power and resource distribution, rules, norms and values existing in the organizational systems need to be examined. Rather than a special case to be treated in special ways, conflict occurs in the routines of work and the norms embedded in everyday social interaction as organizational members go about their daily activities (Bartunek et al., 1992;

Dubinskas, 1992; Friedman, 1992; Friedman \& Berthoin Antal, 2005; Gadlin, 1994, Tucker, 1993, Van Maanen, 1992). 
The conception of "conflict [as] part of the social fabric of organizations" (Bartunek et al., 1992, p. 217) implies that interpretations of issues and problems that make up a conflict are part of - and hence must be understood within - the context in which the conflict occurs, highlighting the role that social context and social process play in shaping the form and trajectory of a conflict. Murnighan and Conlon (1991) for example, found that interpretations, together with many other factors such as experiences, culture, and goals, influence and underpin the disputants' approaches to conflict management. With these developments, we begin to see scholars (e.g. Cloven, \& Roloff, 1991; Kolb, 2008; Lewicki, \& Gray, 2003; Mather \& Yngvesson, 1980; Mikkelsen, 2013, Volkema, Farquhar, \& Bergmann, 1996) giving special attention to the social processes of how conflict is framed and made sense of as important for understanding local strategies used in handling conflict.

Conflict as an organizational phenomenon has been understood by communication scholars through an interpretive approach to the study of conflict and the constitutive relationship between communication and conflict (e.g. Brummans, Putnam, Gray, Hanke, Lewicki, \& Wiethoff, 2008; Mease \& Terry, 2012; Nicotera \& Mahon, 2013). Influenced by Weick (1979), who was among the first to posit that communication is the means by which organizing occurs, conflict is not seen as static but comprised by inherently dynamic processes of communicating. Communication scholars such as Kusztal (2002), Putnam (2010), Sheppard \& Aquino (2013) take particular interest in the hegemonic and performative role of language and symbols in shaping and co-developing conflict, inspiring research into the discourses of conflict, while others (Brummans et al., 2008; DeWulf, Gray, Putnam, Lewicki, Aarts, Bouwen, \& van Woerkum, 2009; Gray, 2003; Mikkelsen \& Gray, 2016) focus on framing and issue development in conflict and language's constitutive effects on social interaction in conflict (Mease \& Terry, 2012; Nicotera \& Mahon, 2013; Putnam, Nicotera, \& McPhee, 2009). From this interpretive approach to conflict we learn that communication should not 
be seen as a variable affecting conflict outcomes but is a performative aspect of conflict (Putnam, 2013). Conflict is seen as a performance in Goffmanian terms (Goffman, 1959) to which involved parties and observers attach different meanings that may change over time and which can be interpreted in any number of different ways.

Conflict as a social construction. It was an article by Felstiner, Abel, and Sarat (1980) on 'Naming, blaming, and claiming' that laid the foundation for conceptualizing conflict as a socially constructed phenomenon by arguing that conflict, as a thing in itself, is meaningless: "[D]isputes are not things: they are social constructs. Their shapes reflect whatever definition the observer gives to the concept" (pp. 631-632). In a comment on his study of conflict management among the British Police Force, Van Maanen (1992) similarly articulated the importance of meaning in conflict: "Meaning is so critical because there is absolutely nothing inherent in the notion of conflict that is strictly independent of human observation and the making of meaning" (p. 55). Further endorsed by the interpretive turn in organization and management theory, communication scholars began to study how disputants interpret and talk about conflict and how it is performed at different times and in different places.

Scholars, working from a conception of conflict as a social construction, place an emphasis on the role that social context plays in interpretation and conceptualization of conflict (Bartunek et al., 1992; Gadlin, 1994; Kolb, 2008; Mikkelsen, 2013). These scholars take an interest in the variety of ways conflict is handled in organizations in terms of culturally and locally governed choice. By assuming conflict as omnipresent, they acknowledge that conflict can be expressed in subtle ways (Kolb \& Bartunek, 1992; Martin, 1992; Morrill, 1995): it is not always visible, acknowledged, or verbalized. People in organizations can be in conflict without labeling their relationship as such. The concept of conflict is an analytical rather than simply descriptive category. 
The conceptualization of conflict as a social construction is underpinned by an interpretive epistemology and qualitative research methodologies. Researchers (e.g. Kusztal, 2002; Morrill, 1989) using qualitative methodologies aim to gain insight into the insider's context-specific experience and view of conflict and the processes through which meaning is generated. Conflict research informed by such constructivist methodological presuppositions aims to broaden the understanding of conflict and conflict handling in organizations. Prescribing specific applied steps to deal with conflict is not the ambition. That said, providing practitioners with diverse explanations of conflict may inform action. Conflict research conducted from this conception of conflict is thus mainly descriptive rather than normative.

Summing up, conflict was traditionally explored as an interpersonal phenomenon in which it was assumed that all conflict followed the principles of interaction dynamics premised on personto-person relations. The third shift broadened this traditional view of conflict as a dyadic phenomenon. It generated a constructivist perspective on conflict that argued that conflict should be studied as an organizational phenomenon. Conflict, along with its interpretation, and the forms it may take, is a practice shaped by the context in which it occurs. The shift from psychologically oriented analyses to studying conflict as a practice embedded as an organizational and conceptual phenomenon generated contestation over the performative meaning of the term conflict.

\section{Conclusion and Implications}

Even though ontological and epistemological commitments are rarely openly displayed within the organizational conflict research literature and may often even be unrecognized by its readers, we nevertheless set out to investigate how organizational conflict has been constructed genealogically, and with what consequences. We found that the study of organizational conflict has undergone three major shifts that have established diverse traditions of theorizing, creating specific grounds for contestation: the first theoretical shift, from viewing conflict as dysfunctional to the pursuit of order 
to viewing it as constructive, created contestation over the functional essence of the term; the second theoretical shift, from normative prescriptions to descriptions of what disputants actually do in conflict, generated contestation over the descriptive essence of the term; the third theoretical shift, from psychologically oriented analyses to studying conflict as a practice that occurs as an organizational phenomenon, generated contestation over the performative essence of the term. While these shifts have occurred separately over periods of several decades, each of them has broadened and generated new strands of conflict research.

The diversity of ontological and epistemological commitments leads to different ways of conceptualizing and engaging with conflict and is a key feature of the theoretical assumptions that influence how researchers make things intelligible and the production of knowledge within the field. It is these commitments that make the term conflict an essentially contested concept. Accordingly, we were able to identify three distinct and competing theoretical positions on the meaning of conflict that frame studies of conflict at work: conflict as a distinct behavioral phenomenon, conflict as an instrumental means, and conflict as a social construction. Each of these incommensurable theoretical positions is rooted in significant philosophical presuppositions about what conflict is and what it means for the organization. Moreover, each theoretical position embraces distinct methodological orientations for researching conflict and holds distinct objectives for yielding scientific knowledge about conflict.

In the end, methodologies rest upon assumptions about the real status of the phenomenon under study, constituted by an applied ontology and epistemology (Hatch \& Yanow, 2008; Johnson \& Duberley, 2000). While much conflict research has been somewhat unreflexive about its ontological grounds, our contribution encourages an awareness of and interest in not only theory generation as an output of the research process but also "the process of theorizing" (Weick, 1995, p. 387). As an important part of generating theory, we expect there is much to learn by first becoming 
more explicit about our philosophical presuppositions because they condition the type of organizational knowledge we acquire; thus, we have placed the different strands of conflict theory within more fundamental debates of ontology and epistemology. However, we do not argue that these are merely the preserve of professional academic discourse: we see their contours expressed in the lay theorizing of everyday life.

Having established that different conceptual positions concerning the nature of conflict are constituted by contestable differences, a significant question remains: why are these differences not explicitly discussed in conflict research literature? We believe that this relates, first, to the fact that organizational conflict research is overwhelmingly embedded within existing and foundational theoretical frameworks that are reinforced through referencing processes that defer to the existing theoretical and methodological communities. Hence, there has been a reproduction of theoretical positions developed from positivist or objectivist research paradigms, the two dominant frameworks of conflict types and conflict management styles (see e.g. Jehn, 1995; Kilmann \& Thomas, 1977; Rahim, 1983). The upshot is, as Tjosvold (2008) argues, that current conflict definitions and research reinforce "popular misconceptions rather than challenging them" (p. 448). Second, in practical terms the field has been overridingly normatively preoccupied with the instrumental outcomes of conflict.

In the past, there has been an almost total separation between the two major research strands that work with conflict types and conflict management approaches or styles, respectively. Although these two main research strands take a particular interest in conflict and its management at the interpersonal level of analysis, they are largely independent research areas. We have only recently begun to see studies that combine these research areas by examining the relationships between conflict management styles and conflict types (see DeChurch et al., 2013; Leon-Perez, Medina, Arenas and Munduate, 2015). Secondly, the literature on the positive versus negative 
effects of conflict has been meta-analyzed no less than four times (DeChurch, Mesmer-Magnus, \& Doty, 2013; De Dreu \& Weingart, 2003; de Wit, Greer, \& Jehn, 2012; O’Neill, Allen, \& Hastings, 2013) since the turn of the millennium due to contradictory findings on the direct effects of task conflict on team outcomes such as productivity and performance. An overriding interest in the instrumental outcomes of conflict diverts attention from conceptual debate and those more sophisticated theoretical developments that capture the complex and dynamic nature of conflict. There is little discussion of multiple or contrasting interpretations of conflict within the different research strands.

For the future, we suggest that research should focus on more detailed ethnographies of actual conflicts in practice, grounded in rich empirical data, such as Mikkelsen and Gray (2016) discuss, in order to explore in detail the different assumptions relied upon in differential sensemaking that produces conflict situations. In doing so, the view that conflict routinely arises out of imbalanced power relationships and differential interests of gender, one might think, is ripe for reappraisal in the light of the \#MeToo movement, spotlighting the systematic effect of gender power imbalances in producing aggravated sexual harassment in organizations. Feminist theorizing and conflict research in international studies, in the classic macro organizational analysis of state conflicts, wars and social movement struggles (Sharoni, 2017) is a rich resource to be explored, as are a small number of contributions to mainstream conflict research, amongst which one would suggest (Putnam, 2006; Putnam and Kolb, 2000; Kolb and Putnam, 1997; Buzzanell and Liu, 2007; Bowles and McGinn, 2008). The focus on systematic institutional bias and discrimination afforded by feminist research provides a strongly substantive arena in which the strengths of diverse contributions can be engaged in dialogue.

We have provided insight into the context and dynamics of conflict research. Our examination of conflict research literature clearly reveals that much of modern conflict research 
views conflict and conflict management as having a functional, descriptive or performative essence. Our conceptual essay is intended to stimulate scholars' participation in what is at present a somewhat rare discussion about how conflict is conceptualized; by doing so we may engage collectively in inquiry into conflict that is less of a closed circle of the like minded and thus be able to extend our understanding of organizational conflict as a phenomenon that not only has functions and can be described but also is performed as a practice. 


\section{References}

Amason, A. (1996). Distinguishing the effects of functional and dysfunctional conflict on strategic decision making: Resolving a paradox for top management teams. Academy of Management Journal, 39(1): 123-148.

Antonioni, D. (1998). Relationship between the big five personality factors and conflict management styles. International journal of conflict management, 9(4): 336-355.

Aquino, K. (2000). Structural and individual determinants of workplace victimization: The effects of hierarchical status and conflict management style. Journal of Management, 26(2): 171-193.

Aritzeta, A., Ayestaran, S., \& Swailes, S. (2005). Team role preference and conflict management styles. International Journal of conflict management, 16(2): 157-182.

Barki, H., \& Hartwick, J. (2004). Conceptualizing the construct of interpersonal conflict. International Journal of Conflict Management, 15(3): 216-244.

Barley, S. (1991). Contextualising conflict: Notes on the anthropology of disputes and negotiations. In R. Lewicki, B. Sheppard, \& R. Bies (Eds.), Research on negotiation in organizations: Handbook of negotiation research vol. 3 (pp. 165-199). US: JAI Press Inc.

Bartunek, J., Kolb, D., \& Lewicki, R. (1992). Bringing conflict out from behind the scenes: Private, informal, and nonrational dimensions of conflict in organizations. In D. Kolb, \& J. Bartunek (Eds.), Hidden conflict in organizations: Uncovering behind-the-scenes disputes (pp. 209-228). US: Sage Publication Inc.

Bayazit, M., \& Mannix, E. (2003). Should I stay or should I go? Predicting team members' intent to remain in the team. Small Group Research, 34, 290-321. 
Bazerman, M.H., Loewenstein, G, \& Moore, D.A. Why Good Accountants Do Bad Audits. Harvard Business Review, November, 2002.

Behfar, K., Mannix, E., Peterson, R., \& Trochim, W. (2011). Conflict in small groups: the meaning and consequences of process conflict. Small Group Research, 42(2): 127-176.

Bendersky, C., \& Hays, N. (2012). Status conflict in groups. Organization Science, 23(2): 323-340.

Blake, R., \& Mouton, J. (1964). The managerial grid. Houston, TX: Gulf.

Borbély, A., \& Caputo, A. (2017). Approaching negotiation at the organizational level. Negotiation and Conflict Management Research, 10(4): 306-323.

Bordone, R., \& Moffitt, M. (2006). Create Value out of Conflict. Negotiation, 9(6): 2-6.

Boulding, K. (1957). Organization and conflict. Journal of Conflict Resolution, 1(2): 122-134.

Bowles, H. R., \& McGinn, K. L. (2008). Untapped Potential in the Study of Negotiation and Gender Inequality in Organizations. Academy of Management annals, 2(1), 99-132.

Bradley, B., Postlethwaite, B., Klotz, A., Hamdani, M., \& Brown, K. (2012). Reaping the benefits of task conflict in teams: The critical role of team psychological safety climate. Journal of Applied Psychology, 97(1): 151-158.

Brewer, N., Mitchell, P., \& Weber, N. (2002). Gender role, organizational status, and conflict management styles. International Journal of Conflict Management, 13(1): 78-94.

Brummans, B., Putnam, L., Gray, B., Hanke, R., Lewicki, R., \& Wiethoff, C. (2008). Making sense of intractable multiparty conflict: A study of framing in four environmental disputes.

Communication Monographs, 75(1): 25-51. 
Burrell, G. (1996). Normal science, paradigms, metaphors, discourses and genealogies of analysis. In S. Clegg, C. Hardy, \& W. Nord (Eds.), Handbook of Organization Studies (pp. 642-650). Thousand Oaks: Sage publication Ltd.

Buzzanell, P. and Liu, M., 2007. It'sgive and take' Maternity leave as a conflict management process. Human Relations, 60(3), pp.463-495.

Chan, J., Sit, E., \& Lau, W. (2014). Conflict management styles, emotional intelligence and implicit theories of personality of nursing students: A cross-sectional study. Nurse education today, 34(6): 934-939.

Choi, Y. (2013). The influence of conflict management culture on job satisfaction. Social Behavior and Personality: an international journal, 41(4): 687-692.

Clegg, S., Mikkelsen, E., \& Sewell, G. (2015). Conflict: Organizational. In J. Wright (Ed.), The international encyclopedia of social and behavioral sciences (2nd ed.) Elsevier Science.

Cloven, D., \& Roloff, M. (1991). Sense-Making activities and interpersonal conflict:

Communicative cures for the mulling blues. Western Journal of Speech Communication, 55, 134158.

Collins, R. (2009). Conflict Sociology: A Sociological Classic Updated. (Abridged and updated by Sanderson, S) Boulder, CO: Paradigm publishers.

Coser, L. (1956). Functions of social conflict. New York: The Free Press.

De Dreu, C. (1997). Productive conflict: the importance of conflict management and conflict issue. In C. De Dreu, \& E. Van de Vliert (Eds.), Using conflict in organizations (pp. 9-22). London: Sage Publications Ltd. 
De Dreu, C. (2006). When too little or too much hurts: Evidence for a curvilinear relationship between task conflict and innovation in teams. Journal of Management, 32(1): 83-107.

De Dreu, C. (2008). The virtue and vice of workplace conflict: Food for (pessimistic) thought. Journal of Organizational Behavior, 29(1): 5-18.

De Dreu, C., \& Beersma, B. (2005). Conflict in organizations: Beyond effectiveness and performance. European Journal of Work and Organizational Psychology, 14(2): 105-117.

De Dreu, C., \& Gelfand, M. (2008). Conflict in the workplace: Sources, functions, and dynamics across multiple levels of analysis. In C. De Dreu, \& M. Gelfand (Eds.), The psychology of conflict and conflict management in organizations (pp. 3-54). New York: Lawrence Erlbaum Associates.

De Dreu, C., \& Van de Vliert, E. (1997). Using conflict in organizations. London: Sage Publications Ltd.

De Dreu, C., \& Weingart, L. (2003). Task versus relationship conflict, team performance, and team member satisfaction: A meta-analysis. The Journal of Applied Psychology, 88(4): 741-749.

De Dreu, C., Harinck, F., \& Van Vianen, A. (1999). Conflict and performance in groups and organizations. In C. Cooper, \& I. Robertson (Eds), International review of industrial and organizational psychology (pp. 376-405). Chichester, UK: Wiley.

De Dreu, C., van Dierendonck, D., \& Dijkstra, M. (2004). Conflict at work and individual wellbeing. International Journal of Conflict Management, 15(1): 6-26.

de Wit, F., Greer, L., \& Jehn, K. (2012). The paradox of intragroup conflict: A meta-analysis. Journal of Applied Psychology, 97(2): 360-390. 
de Wit, F., Jehn, K., \& Scheepers, D. (2013). Task conflict, information processing, and decisionmaking: The damaging effect of relationship conflict. Organizational Behavior and Human Decision Processes, 122(2): 177-189.

DeChurch, L., Mesmer-Magnus, J., \& Doty, D. (2013). Moving beyond relationship and task conflict: Toward a process-state perspective. Journal of Applied Psychology, 98: 559-578.

Deutsch, M. (1949). A theory of cooperation and competition. Human Relations, 2(1): 129-151.

Deutsch, M. (1973). The resolution of conflict: Constructive and destructive processes. New Haven, CT: Yale University Press.

Deutsch, M. (1990). Sixty years of conflict. The International Journal of Conflict Management, 1: 237-263.

Dewulf, A., Gray, B., Putnam, L., Lewicki, R., Aarts, N., Bouwen, R., \& Van Woerkum, C. (2009). Disentangling approaches to framing in conflict and negotiation research: A meta-paradigmatic perspective. Human relations, 62(2): 155-193.

Druckman, D. (2005). Doing research: Methods of inquiry for conflict analysis. Thousand Oaks, CA: Sage Publications.

Dubinskas, F. (1992). Culture and conflict: The cultural roots of discords. In D. Kolb, \& J. Bartunek (Eds.), Hidden conflict in organizations: Uncovering behind-the-scenes disputes (pp. 187-208). US: Sage Publication Inc.

Eiseman, J. (1978). Reconciling “incompatible” positions. The Journal of Applied Behavioral Science, 14(2): 133-150.

Farh, J., Lee, C., \& Farh, C. (2010). Task conflict and team creativity: A question of how much and when. Journal of Applied Psychology, 95(6): 1173-1180. 
Felstiner, W., Abel, R., \& Sarat, A. (1980). Emergence and transformation of disputes: Naming, blaming, claiming... Law \& Soc'y Rev., 15(3/4): 631-654.

Fink, C. (1968). Some conceptual difficulties in the theory of social conflict. Journal of Conflict Resolution, 12(4): 412-460.

Foucault, M. (2003). The Essential Foucault: Selections from Essential works of Foucault, 19541984. New York, NY: The New Press.

Friedman, R. (1992). The culture of mediation: Private understandings in the context of public conflict. In D. Kolb, \& J. Bartunek (Eds.), Hidden conflict in organizations: Uncovering behindthe-scenes disputes (pp. 143-164). US: Sage Publication Inc.

Friedman, V., \& Berthoin Antal, A. (2005). Negotiating reality: A theory of action approach to intercultural competence. Management Learning, 36(1): 69-86.

Gadlin, H. (1994). Conflict resolution, cultural differences, and the culture of racism. Negotiation Journal, 10(1): 33-47.

Gallie, W. (1956). Essentially Contested Concepts. Proceedings of the Aristotelian Society, 56: $167-198$.

Gamero, N., Gonzalez-Roma, V., \& Peiro, J. (2008). The influence of intra-team conflict on work teams' affective climate: A longitudinal study. Journal of Occupational and Organizational Psychology, 81(1): 47-69.

Garver, E. (1978). Rhetoric and essentially contested arguments, Philosophy and Rhetoric, 11(3): 156-172.

Goffman, E. (1959). The Presentation of Self in Everyday Life. Harmondsworth, Penguin. 
Goodboy, A., \& Bolkan, S. (2013). Instructional dissent as a function of student conflict styles. Communication Research Reports, 30(3): 259-263.

Gray, B. (1985). Conditions facilitating interorganizational collaboration. Human Relations, 38(10): 911-936.

Gray, B. (2003). Framing of environmental disputes. In R. Lewicki, B. Gray, \& M. Elliot (Eds.), Making Sense of Intractable Environmental Conflicts (pp. 11-34). US: Islands Press.

Gray, B., Coleman, P., \& Putnam, L. (2007). Introduction: Intractable conflict: New perspectives on the causes and conditions for change. American Behavioral Scientist, 50(11): 1415-1429.

Gray, J. (1977). On the Contestability of Social and Political Concepts, Political Theory, 5(3): 331348.

Greer, L., Jehn, K., \& Mannix, E. (2008). Conflict transformation: An exploration of the interrelationships between task, relationship, and process conflict. Small Group Research, 39(3): 278302.

Hatch, M., \& Yanow, D. (2008). Methodology by metaphor: Ways of seeing in painting and research. Organization Studies, 29(1): 23-44.

Hegel, G. (1975). Lectures on the philosophy of world history: introduction, reason in history (translated from the German edition of Johannes Hoffmeister from Hegel papers assembled by H. B. Nisbet) New York, NY: Cambridge University Press.

Hocker, J., \& Wilmot, W. (1991). Interpersonal conflict. Dubuque, IA: Wm. C. Brown.

Jaffe, D. (2008). Conflict at work throughout the history of organizations. In C. De Dreu, \& M.

Gelfand (Eds.), The psychology of conflict and conflict management in organizations (pp. 55-80).

New York: Lawrence Erlbaum Associates. 
Jameson, J. (2004). Negotiating autonomy and connection through politeness: A dialectical approach to organizational conflict management. Western Journal of Communication (includes Communication Reports), 68(3): 257-277

Jehn, K. (1994). Enhancing effectiveness: An investigation of advantages and disadvantages of value-based intragroup conflict. International Journal of Conflict Management, 5(3): 223-238.

Jehn, K. (1995). A multimethod examination of the benefits and detriments of intragroup conflict. Administrative Science Quarterly, 40(2): 256-282.

Jehn, K. (1997). A qualitative analysis of conflict types and dimensions in organizational groups. Administrative Science Quarterly, 42(3): 530-557.

Jehn, K., \& Mannix, E. (2001). The dynamic nature of conflict: A longitudinal study of intragroup conflict and group performance. Academy of Management Journal, 44(2): 238-251.

Jehn, K., Greer, L., Levine, S., \& Szulanski, G. (2008). The effects of conflict types, dimensions, and emergent states on group outcomes. Group Decision and Negotiation, 17(6): 465-495.

Johnson, P., \& Duberley, J. (2000). Understanding management research: An introduction to epistemology. London: Sage.

Katz, D., \& Kahn, R. (1978). The social psychology of organizations. New York: Wiley.

Kilmann, R., \& Thomas, K. (1977). Developing a forced-choice measure of conflict-handling behavior: The "MODE” instrument. Educational and Psychological Measurement, 37(2): 309-325.

King, W., \& Miles, E. (1990). What we know — and don't know— about measuring conflict. Management Communication Quarterly, 4(2): 222-243.

Knapp, M., Putnam, L., \& Davis, L. (1988). Measuring interpersonal conflict in organizations: Where do we go from here? Management Communication Quarterly, 1(3): 414-429. 
Kolb, D. (2008). Making sense of an elusive phenomenon. In C. De Dreu, \& M. Gelfand (Eds.), The psychology of conflict and conflict management in organizations (pp. 425-433). New York: Lawrence Erlbaum Associates.

Kolb, D., \& Bartunek, J. (1992). Hidden conflict in organizations: Uncovering behind-the-scenes disputes. US: Sage Publication Inc.

Kolb, D., \& Putnam, L. (1992). The multiple faces of conflict in organizations. Journal of Organizational Behavior, 13(3): 311-324.

Kolb, D.M., and Putnam, L.L. (1997) Through the Looking Glass: Negotiation Theory Refracted Through the Lens of Gender. In S. Gleason (ed.), Workplace Dispute Resolution: Directions for the Twenty-First Century. East Lansing: Michigan State University.

Kuhn, T., \& Poole, M. (2000). Do conflict management styles affect group decision making? Evidence from a longitudinal field study. Human Communication Research, 26(4): 558-590. Kusztal, I. (2002). Discourses in the use and emergence of organizational conflict. Conflict Resolution Quarterly, 20(2): 231-247.

Lê, J., \& Jarzabkowski, P. (2015). The role of task and process conflict in strategizing. British Journal of Management, 26(3): 439-462.

Leon-Perez, J., Medina, F., Arenas, A., Munduate, L. (2015). The relationship between interpersonal conflict and workplace bullying. Journal of Managerial Psychology, 30(3): 250 - 263.

Lewicki, R., \& Gray, B. (2003). Introduction. In R. Lewicki, B. Gray, \& M. Elliot (Eds.), Making Sense of Intractable Environmental Conflicts (pp. 1-10). US: Islands Press.

Lewicki, R., Weiss, S., \& Lewin, D. (1992). Models of conflict, negotiation and third party intervention: A review and synthesis. Journal of Organizational Behavior, 13(3): 209-252. 
Lukes, S. (2005). Power: A Radical View (2 ${ }^{\text {nd }}$ edition) London: Palgrave Macmillan.

Mack, R., \& Snyder, R. (1957). The analysis of social conflict--toward an overview and synthesis. Conflict Resolution, 1(2): 212-248.

March, J., \& Simon, H. (1958). Organizations. London: Wiley.

Martin, J. (1992). The suppression of gender conflict in organizations. In D. Kolb, \& J. Bartunek (Eds.), Hidden conflict in organizations: Uncovering behind-the-scenes disputes (pp. 165-186). US: Sage Publication Inc.

Marx, K. (1976). Capital (Vol 1) Harmondsworth: Penguin

Mather, L., \& Yngvesson, B. (1980). Language, audience, and the transformation of disputes. Law and Society Review, 15(3-4): 775-825.

Mease, J., \& Terry, D. (2012). [Organizational (Performance] of Race): The Co-Constitutive Performance of Race and School Board in Durham, NC. Text and Performance Quarterly, 32(2): 121-140.

Mikkelsen, E. (2013). An Analysis of the Social Meanings of Conflict in Nonprofit Organizations. Nonprofit and Voluntary Sector Quarterly, 42(5): 923-941.

Mikkelsen, E., \& Gray, B. (2016). Everyday conflict at work: an organizational sensemaking ethnography. In A. Pedersen, \& D. Humle (Eds.), Doing Organizational Ethnography (pp. 17-39). New York: Routledge.

Morrill, C. (1989). The management of managers: Disputing in an executive hierarchy. Sociological Forum, 4(3): 387-407.

Morrill, C. (1995). The executive way: Conflict management in corporations. Chicago: University of Chicago Press. 
Murnighan, J., \& Conlon, D. (1991). The dynamics of intense work groups: A study of British string quartets. Administrative Science Quarterly, 36(2): 165 - 186.

Myers, L., \& Larson, R. (2005). Preparing students for early work conflicts. Business communication quarterly, 68(3): 306-317.

Nicotera, A., \& Mahon, M. (2012). Between rocks and hard places: Exploring the impact of structurational divergence in the nursing workplace. Management Communication Quarterly

O'Neill, T., Allen, N., \& Hastings, S. (2013). Examining the "Pros" and "Cons" of Team Conflict: A Team-Level Meta-Analysis of Task, Relationship, and Process Conflict. Human Performance, 26(3): 236-260.

O’Connell, M. (1971). Intraorganizational conflict. Unpublished paper, University of Wisconsin, Milwaukee.

Olekalns, M., Putnam, L., Weingart, L., \& Metcalf, L. (2008). Communication processes and conflict management. In C. De Dreu, \& M. Gelfand (Eds.), The psychology of conflict and conflict management in organizations (pp. 81-114). US: Taylor Francis Group.

Olson, B., Parayitam, S., \& Bao, Y. (2007). Strategic decision making: The effects of cognitive diversity, conflict, and trust on decision outcomes. Journal of Management, 33(2): 196-222.

Paul, G. D., Geddes, D., Jones, T. S., \& Donohue, W. A. (2016). Revitalizing conflict research with a communication perspective: Celebrating and learning from Linda Putnam's contributions to the study of conflict. Negotiation and Conflict Management Research, 9(4): 309-331.

Perrow, C. (1967). A framework for the comparative analysis of organizations. American Sociological Review, 32(2): 194-208.

Polybius (1922). The Histories, Books 1-2, Loeb Classical Library (January 1, 1922) 
Pondy, L. (1967). Organizational conflict: Concepts and models. Administrative Science Quarterly, 12(2): 296-320.

Pondy, L. (1992). Reflections on organizational conflict. Journal of Organizational Behavior, 13(3): $257-261$.

Pruitt, D., \& Rubin, J. (1986). Social conflict: Escalation, stalemate, and settlement. New York: McGraw-Hill.

Putnam, L. (2010). Negotiation and discourse analysis. Negotiation journal, 26(2): 145-154.

Putnam, L. (2013). Definitions and approaches to conflict and communication. In J. Oetzel, \& S. Ting-Toomey (Eds.), The SAGE handbook of conflict and communication (pp. 1-32). Sage.

Putnam, L. L. (2006). Definitions and approaches to conflict and communication. The Sage handbook of conflict communication: Integrating theory, research, and practice, 1-32.

Putnam, L., \& Poole, M. (1987). Conflict and negotiation. In F. Jablin, L. Putnam, K. Roberts, \& L. Porter (Eds.), Handbook of organizational communication: An interdisciplinary perspective (pp. 549-599). CA: Sage Publications, Inc.

Putnam, L., \& Wilson, C. (1982). Communicative strategies in organizational conflict: Reliability and validity of a measurement scale. In M. Burgoon (Ed.), Communication yearbook 6 (pp. 629652). Newbury Park, CA: Sage.

Putnam, L., and Kolb, D. (2000). Rethinking Negotiations: Feminist Views of Communications and Exchange. In P. Buzannell (ed.) Rethinking Organizational Communications from Feminist Perspectives. Newbury Park: Sage. 
Putnam, L., Nicotera, A., \& McPhee, R. (2009). Introduction. Communication Constitutes Organization. In L. Putnam, \& A. Nicotera (Eds.), Building theories of Organization: The Constitutive Role of Communication (pp. 1-20). New York: Routledge.

Rahim, M. (1983). A measure of styles of handling interpersonal conflict. Academy of Management Journal, 26(2): 368-376.

Rahim, M. (2000). Managing conflicts in organizations. US: Greenwood Publishing Group.

Rahim, M. (2002). Toward a theory of managing organizational conflict. International Journal of Conflict Management, 13(3): 206-235.

Raiffa, H. (1982). The Art and Science of Negotiation. Cambridge, MA: Harvard Univ. Press.

Raiffa, H., Richardson, J. and Metcalfe, D. (2003). Negotiation Analysis: The Science and Art of Collaborative Decision. Cambridge, MA: Harvard Univ. Press.

Renwick, P. (1975). Impact of topic and source of disagreement on conflict management. Organizational Behavior and Human Performance, 14(3): 416-425.

Runde, C. (2014). Conflict Competence in the Workplace. Employment Relations Today, 40(4): 2531.

Saeed, T., Almas, S., Anis-ul-Haq, M., \& Niazi, G. (2014). Leadership styles: relationship with conflict management styles. International Journal of Conflict Management, 25(3): 214-225.

Schlaerth, A., Ensari, N., \& Christian, J. (2013). A meta-analytical review of the relationship between emotional intelligence and leaders' constructive conflict management. Group Processes \& Intergroup Relations, 16(1): 126-136.

Schmidt, S., \& Kochan, T. (1972). Conflict: Toward conceptual clarity. Administrative Science Quarterly, 17(3): 359-370. 
Shah, P., \& Jehn, K. (1993). Do friends perform better than acquaintances? The interaction of friendship, conflict, and task. Group Decision and Negotiation, 2(2): 149-165.

Sharoni, S. (2017) Conflict Resolution: Feminist Perspectives, In Marlin-Bennett, R. (Ed.), Oxford Research Encyclopedia of International Studies, available at http://intentantional studies.oxfordre.com, accessed March 22, 2018.03.22

Sheppard, B. (1992). Conflict research as schizophrenia: The many faces of organizational conflict. Journal of Organizational Behavior, 13(3): 325-334.

Sheppard, L., \& Aquino, K. (2013). Much ado about nothing? Observers' problematization of women's same-sex conflict at work. The Academy of Management Perspectives, 27(1): 52-62.

Shipka, T. (1969). Social Conflict and Re-construction. Unpublished doctoral dissertation, Boston College: Massachusetts.

Somech, A., Desivilya, H., \& Lidogoster, H. (2009). Team conflict management and team effectiveness: The effects of task interdependence and team identification. Journal of Organizational Behavior, 30(3): 359-378.

Song, M., Dyer, B., \& Thieme, R. (2006). Conflict management and innovation performance: An integrated contingency perspective. Journal of the Academy of Marketing Science, 34(3): 341-356.

Spector, P., \& Bruk-Lee, V. (2008). Conflict, Health, and Well-Being. In C. De Dreu, \& M. Gelfand (Eds). The psychology of conflict and conflict management in organizations (pp. 267-288). US: Taylor Francis Group.

Swanton, C. (1985). On the "Essential Contestedness" of Political Concepts, Ethics, 95(4): 811827. 
Tanner, R. (2014). Organizational conflict: Get used to it and use it. May, 13, 2014. Amazon Digital Services.

Thomas, K. (1976). Conflict and conflict management. In Dunnette, M (ed) Handbook in industrial and organizational psychology: 889-935. Chicago: Rand McNally.

Thomas, K. (1992). Conflict and conflict management: Reflections and update. Journal of Organizational Behavior, 13(3): 265-274.

Thompson, L. (1990). Negotiation behavior and outcomes: Empirical evidence and theoretical issues. Psychological bulletin, 108(3), 515.

Thucydides. (413 BCE). The History of the Peloponnesian War.

http://classics.mit.edu/Thucydides/pelopwar.html, first accessed May 52013.

Tjosvold, D. (1985). Implications of controversy research for management. Journal of Management, 11(3): 21-37.

Tjosvold, D. (1991). Rights and responsibilities of dissent: Cooperative conflict. Employee Responsibilities and Rights Journal, 4, 13-23.

Tjosvold, D. (2006). Defining conflict and making choices about its management: Lighting the dark side of organizational life. International Journal of Conflict Management, 17(2): 87-95.

Tjosvold, D. (2008). Conflicts in the Study of Conflict in Organizations. In De Dreu, C, \& Gelfand, M (eds) The psychology of conflict and conflict management in organizations. US: Taylor Francis Group, 445-453.

Tjosvold, D. (2008). The conflict-positive organization: It depends upon us. Journal of Organizational Behavior, 29, 19-28. 
Tjosvold, D., Dann, V., \& Wong, C. (1992). Managing conflict between departments to serve customers. Human Relations, 45(10): 1035-1054.

Tsoukas H. (2016). Don't simplify, complexify: from disjunctive to conjunctive theorizing in organization and management studies. Journal of Management Studies DOI: 10.1111/joms.12219 Tucker, J. (1993). Everyday forms of employee resistance: how temporary workers handle conflict with the employers. Sociological Forum, 8(1): 25-45.

Van de Vliert, E. (1998). Conflict and conflict management. In P. Drenth, H. Thierry, \& C. de Wolff (Eds.), Handbook of work and organizational psychology (pp. 351-376). UK: Taylor \& Francis.

Van de Vliert, E., \& Prein, H. (1989). The difference in meaning of forcing in the conflict management of actors and observers. In M. Rahim (Ed.), Managing conflict: An interdisciplinary approach (51-63). New York: Praeger.

Van Maanen, J. (1992). Drinking our troubles away: Managing conflict in a British police agency. In D. Kolb, \& J. Bartunek (Eds.), Hidden conflict in organizations: Uncovering behind-the-scenes disputes (pp. 32-62). US: Sage Publication Inc.

Volkema, J., Farquhar, K., \& Bergmann, T. (1996). Third-Party sensemaking in interpersonal conflicts at work: A theoretical framework. Human Relations, 49(11): 1437-1454.

Wall, J., \& Callister, R. (1995). Conflict and its management. Journal of Management, 21(3): 515558.

Walton, R. (1969) Interpersonal peacemaking: Confrontations and third-party consultations. Reading, MA: Addison-Wesley. 
Weick, K. (1979). The Social Psychology of Organizing (2nd ed.) Reading, Massachusets: AddisonWesley Pub. Co.

Weick, K. (1995). What theory is not, theorizing is. Administrative Science Quarterly, 40: 385-390.

Weingart, L., Behfar, K., Bendersky, C., Todorova, G., \& Jehn, K. (2015). The directness and oppositional intensity of conflict expression. Academy of Management Review, 40(2): 235-262.

Womack, D. (1988). A review of conflict instruments in organizational settings. Management Communication Quarterly, 1(3): 437-445. 